\title{
PENERAPAN SISTEM TANGGUNG RENTENG PADA KOPERASI WANITA SERBA USAHA "SETIA BUDI WANITA" MALANG
}

\author{
Yayuk Sri Rahayu \\ Fakultas Ekonomi Universitas Islam Negeri Maulana Malik Ibrahim Malang \\ J1. Gajayana No. 50, Telepon (0341) 558881, Fax. (0341) 558881, \\ E-mail: feuinmlg@yahoo.co.id
}

\begin{abstract}
This research aimed to describe the implementation of tanggung renteng system and the role of women at Kopwan Setia Budi Wanita Malang. Tanggung renteng system is a sharing responsibility and implementation of collectivity concept on everyone at cooperation. Descriptive analysis was used to get the answer of the purpose. The results shows, first, the implementation of tanggung renteng system consists of decision making process (acceptance of new member), finansial (loan), risk, and the future of cooperation. The increase in member, asset, omzet, and profit shows the success of implementation of this system. Second, women take a part on cooperation development sinc they can increase family economic and natinal economic in general.
\end{abstract}

Key words : tanggung renteng system, women role, natinal economic

Indonesia mempunyai tiga pelaku ekonomi secara nasional yaitu BUMN, BUMS, dan koperasi. Namun pada kenyataannya hanya koperasi yang berperan dominan sebagai wahana ekonomi kelompok masyarakat ekonomi lemah (Idrus, 2007). Keberadaan koperasi sebagai salah satu pelaku ekonomi nasional merupakan representasi dari golongan ekonomi lemah. Sehingga dapat dikatakan keberadaan koperasi Indonesia dalam konteks kelembagaan dan pengembangan usaha masih dalam upaya pencarian dan penyesuaian dalam sistem ekonomi yang ada.

Konsep koperasi secara esensi sejalan dengan visi kehidupan manusia (terutama Indonesia) yang mengedepankan semangat kebersamaan. Hal tersebut tercermin dalam asas-asas koperasi yang dikemukakan oleh Bung Hatta (Alam, 2007) yaitu pertama, koperasi bertujuan untuk memenuhi kebutuhan 
anggotanya. Dalam mencapai tujuannya koperasi tetap memiliki orientasi ekonomi, mendapatkan keuntungan, tetapi tetap berada dalam tujuannya yang utama. Kedua, koperasi mengemban fungsi sosial dan lebih mengutamakan keberpihakan kepada rakyat miskin. Ketiga, koperasi merupakan persekutuan independen yang merdeka dan tidak lahir atas tekanan atau paksaan. Keempat, koperasi merupakan bentuk usaha yang dijalankan berdasar asas kekeluargaan dan kerjasama.

Ada dua fungsi yang harus dilakukan koperasi yaitu sebagai lembaga usaha dan lembaga pembelajaran bagi anggotanya. Sebagai lembaga usaha, koperasi harus mampu mempertahankan dan mengembangkan assetnya yang pada akhirnya akan meningkatkan kualitas pelayanan pada anggota dan sebagai lembaga pembelajaran, koperasi harus mampu mendidik anggotanya untuk mandiri sehingga dapat meningkatkan kesejahteraan.

Untuk menjawab kedua fungsi lembaga tersebut, koperasi dapat menerapkan sistem tanggung renteng karena sistem ini memuat semangat "berat sama dipikul dan ringan sama dijinjing" dan intinya adalah kebersamaan. Tanggung renteng adalah sebuah sistem yang membagi tanggung jawab secara merata, menerapkan konsep kolektifitas, mulai dari merancang program hingga mengatasi masalah yang dihadapi (Indiyon, 2006). Kelebihan dari sistem ini adalah semua ikut berpikir, bekerja, dan memantau. Tanggung jawab dibagi secara merata sehingga semua berhak mendapatkan akses informasi atas perkembangan usaha dan hasil dari usaha yang dimaksud.

Untuk itu syarat utama dalam sistem tanggung renteng adalah anggota harus berkelompok untuk memahami hak dan kewajiban masing-masing anggota. Setiap kelompok minimal terdiri dari 15 anggota dan maksimal 30 anggota. Semua proses pengambilan keputusan harus melalui musyawarah karena apapun yang diputuskan akan menjadi tanggung jawab seluruh anggota kelompok. Musyawarah dilakukan dalam pengambilan keputusan mengenai penerimaan anggota baru, mengeluarkan anggota, pengajuan pinjaman, dan semua permasalahan kelompok yang terkait dengan adanya kewajiban yang tak terbayar. Jika ada salah satu anggota yang tidak dapat membayar hutangnya maka seluruh anggota kelompok berkewajiban menanggulangi sehingga tidak akan ada tunggakan pembayaran hutang. Hal inilah yang dapat meminimalisasi 
kredit macet atau non performing loan (NPL). Dengan demikian model tanggung renteng akan sangat membantu koperasi yeng mempunyai unit usaha simpan pinjam untuk terus dapat mempertahankan dan mengembangkan assetnya.

Salah satu koperasi yang telah sukses menerapkan sistem tanggung renteng adalah Koperasi Wanita Serba Usaha "Setia Budi Wanita" Malang. Hal ini dibuktikan dari semakin bertambahnya jumlah anggota dan menurunnya nilai kredit macet yang disalurkan kepada anggota.

Berdasarkan latar belakang di atas maka penelitian ini bertujuan untuk mengetahui penerapan sistem tanggung renteng dan peranan wanita pada koperasi wanita serba usaha Setia Budi Wanita Malang.

\section{KOPERASI}

Prof. R.S. Soeriaatmadja (Alam, 2007) mendefinisikan koperasi sebagai suatu perkumpulan dari orang-orang yang atas dasar persamaan derajat manusia, dengan tidak memandang haluan agama dan politik, secara sukarela masuk untuk memenuhi kebutuhan bersama yang bersifat kebendaan atas tanggung jawab bersama. Sedangkan Paul Hubert Casselmen mengemukakan bahwa cooperation is an economic system with social contrast.

Asas-asas koperasi menurut Bung Hatta terdiri dari:

1. Koperasi bertujuan untuk memenuhi kebutuhan anggotanya

2. Koperasi mengemban fungsi sosial dan lebih mengutamakan keberpihakan kepada masyarakat miskin

3. Koperasi merupakan persekutuan independen yang merdeka dan tidak lahir atas tekanan dan paksaan

4. Koperasi merupakan bentuk usaha yang dijalankan berdasar asas kekeluargaan dan kerjasama

Sedangkan jenis-jenis koperasi, sebagai berikut :

1. Jenis koperasi menurut usaha pokok yang dijalankan adalah :
a. Koperasi kredit
b. Koperasi konsumsi
c. Koperasi produksi barang dan jasa 
2. Jenis koperasi berdasarkan unit usaha adalah :
a. Koperasi usaha tunggal
b. Koperasi serba usaha

3. Jenis koperasi menurut lingkungan daerah kerja adalah :
a. Koperasi pasar
b. Koperasi Unit Desa (KUD)
c. Koperasi serba usaha perkotaan, dsb

4. Jenis koperasi menurut lingkup fungsional adalah :
a. Koperasi pegawai negeri
b. Koperasi karyawan
c. Koperasi mahasiswa
d. Koperasi wanita, dsb

Lembaga koperasi kini telah berkembang di seluruh pelosok bumi dan pada tahun 1895 telah berdiri organisasi aliansi koperasi seluruh dunia yaitu International Cooperative Alliance (ICA). Lembaga tersebut berperan sebagai penjaga nilai-nilai koperasi dan untuk meningkatkan kerjasama antar koperasi di seluruh dunia. Pada kongres 100 tahun ICA tahun 1995 semakin mengukuhkan misi sosial koperasi dan lebih memperjelas identitas koperasi, selain itu juga merumuskan sebuah resolusi tentang gender dalam koperasi.

Sasaran utama dari ekonomi kerakyatan adalah menata dan memantapkan kelembagaan koperasi dan sistem koperasi semakin efisien serta dapat berperan utama dalam perekonomian rakyat. Hal tersebut dapat menunjang produktivitas dan efisiensi ekonomi yang berakar dalam masyarakat dan mendukung peran serta koperasi dalam pemerataan, pertumbuhan dan stabilitas ekonomi.

Untuk mencapai sasaran tersebut, maka pembangunan koperasi diarahkan untuk mengembangkan koperasi menjadi badan usaha yang sehat, mandiri, efisien, dan mampu berperan di semua bidang usaha terutama dalam kehidupan ekonomi rakyat serta menjadi sokoguru perekonomian nasional yang tangguh dalam upaya mewujudkan demokrasi ekonomi berdasarkan Pancasila dan Undang-Undang Dasar 1945.

Sesuai dengan arah tersebut maka pembangunan koperasi diselenggarakan melalui penciptaan iklim yang kondusif, pemberian 
kesempatan berusaha seluas-luasnya, peningkatan kemampuan organisasi, manajemen, kewirausahaan, dan permodalan dengan didukung oleh peningkatan jiwa, semangat, dan budaya berkoperasi di tengah-tengah masyarakat.

Pengembangan koperasi di kalangan kaum wanita merupakan salah satu program dalam pembangunan koperasi. Hal ini didasarkan kepada suatu kenyataan bahwa wanita adalah sumber insan pembangunan, di tangan wanitalah insan pembangunan yang tangguh lahir. Oleh karena itu peranan wanita dalam rangka pembangunan Indonesia, perlu ditingkatkan, sesuai dengan dimensi pokok peranan wanita dalam pembangunan, yaitu :

1. Wanita mempunyai hak dan kewajiban yang sama dengan pria dalam pembangunan.

2. Meningkatkan kedudukan wanita dalam masyarakat mulai dari lingkungan keluarga dan peranannya sebagai wanita yang sejajar dengan pria dalam pembangunan.

3. Peran ganda wanita dalam keluarga dan dalam masyarakat secara selaras dan serasi.

4. Pengakuan terhadap kodrat yang harus dilindungi serta harkat dan martabat wanita yang perlu dijunjung tinggi.

5. Perlunya pendidikan dan keterampilan wanita untuk mampu memanfaatkan kesempatan kerja.

6. Perlunya iklim pengembangan sosial budaya yang lebih menopang pada kemajuan wanita

7. Dalam rangka mendorong partisipasi wanita dalam pembangunan perlu meningkatkan kesejahteraan keluarga.

Dalam pembangunan bidang ekonomi pada umumnya dan pembangunan koperasi pada khususnya, kaum wanita telah mengambil peran yang cukup besar baik sebagai anggota, pengurus, pengawas maupun sebagai kader-kader penggerak koperasi. Walaupun demikian peran tersebut masih perlu lebih ditingkatkan di masa yang akan datang karena koperasi yang dikelola oleh kalangan wanita atau koperasi wanita mempunyai peranan strategis di tengah masyarakat dan diharapkan melalui koperasi wanita, 
kelompok-kelompok ekonomi produktif yang beranggotakan wanita dapat lebih diberdayakan menjadi kekuatan ekonomi yang berbasis pada rakyat.

\section{Tanggung Renteng}

Definisi tanggung renteng menurut Puskowanjati (Puskowanjati, 2009) adalah tanggung menanggung diantara anggota dalam satu kelompok atas segala kewajiban terhadap koperasi dengan keterbukaan dan saling mempercayai. Sedangkan menurut Alam (2007) tanggung renteng adalah sebuah sistem yang membagi tanggung jawab secara merata, menerapkan konsep kolektifitas mulai dari merancang program hingga mengatasi masalah yang dihadapi. Rasmiati (Alam, 2007) mendefinisikannya sebagai suatu sistem yang memuat tanggung jawab bersama di antara anggota dalam satu kelompok dengan kewajiban anggota pada kelompoknya atas dasar keterbukaan dan saling mempercayai.

\section{METODE}

\section{Lokasi penelitian}

Penelitian ini dilakukan pada Kopwan Serba Usaha Setia Budi Wanita Malang yang beralamat di Jl. Trunojoyo no. 76 Malang

\section{Jenis penelitian}

Penelitian ini adalah penelitian deskriptif yaitu suatu penelitian yang bertujuan untuk memberikan gambaran atau lukisan secara sistematis, faktual, dan akurat mengenai fenomena yang selidiki (Hasan, 2003). Macam penelitian adalah studi kasus yang bertujuan untuk memberikan gambaran secara mendetail tentang latar belakang, sifat-sifat, serta karakter-karakter yang khas dari kasus, individu, kelompok, institusi, atau masyarakat (Masyhuri, 2006)

\section{Pengumpulan data}

Data yang digunakan terdiri dari data primer dan data sekunder, yaitu :

1. Data primer diperoleh langsung dari sumbernya dengan metode wawancara.

2. Data sekunder diperoleh dari data-data yeng ada di Kopwan SU Setia Budi Wanita Malang dan Puskowanjati Jawa Timur. 


\section{Metode analisis}

Penelitian ini menggunakan metode analisis deskriptif dengan pemaparan dan tabulasi. Data yang diperoleh dideskripsikan dalam bentuk pemaparan dan data time series disajikan dalam bentuk tabulasi.

\section{HASIL DAN PEMBAHASAN}

\section{Sejarah pendirian Kopwan SU Setia Budi Wanita Malang}

Pada tahun 1954 (Setia Budi Wanita, 2009) ibu Mursia Zaafril Ilyas memprakarsai sebuah perkumpulan ibu-ibu yang kemudian berkembang menjadi komunitas arisan. Kemudian ibu Mursia Zaafril Ilyas mengembangkan perkumpulan ini agar tidak hanya sekedar menjadi komunitas arisan tetapi mempunyai misi lain yang lebih maju sehingga mereka sepakat untuk merintis sebuah koperasi sebagai alat unutk membina manusia. Lembaga ini adalah wahana untuk menggali dan mengembangkan potensi wanita yang akan dapat menaikkan derajat dan martabat kaum perempuan. Dengan kesadaran semacam itu komunitas arisan tadi berkembang menjadi koperasi simpan pinjam dan mereka mendeklarasikan Pra koperasi yang diberi nama Setia Budi Wanita. Maka sejak saat itu dilakukan sosialisasi dan perekrutan anggota baru, para anggota yang ada menyebar mencari anggota baru dan setiap sepuluh orang anggota dapat membentuk satu kelompok. 23 tahun kemudian pada tanggal 30 Desember 1977 komunitas Setia Budi Wanita disahkan sebagai Badan Hukum dari menteri koperasi RI dengan nomor : 3992 / BH/ II/77 dengan nama Koperasi Serba Usaha Setia Budi Wanita Malang.

Di tengah usahanya yang sedang maju dan berkembang Kopwan SBW pernah lumpuh total selama 4 tahun yaitu pada tahun 1982. Sentralisasi kebijakan oleh manajer keuangan pada sejumlah program usaha menjadi awal guncangan bagi koperasi yaitu ketidaktepatan dalam pengambilan keputusan dan ketidakakuratan dalam membaca realitas dan koordinasi. Hal ini menyebabkan ribuan anggotanya mengundurkan diri dan lima dari enam jenis usaha yang ada ditutup dan hanya menyisakan satu jenis usaha yaitu simpan pinjam. Sistem tanggung renteng pun diuji penerapannya dan pada perkembangan selanjutnya dengan semangat tanggung renteng semua anggota 
yang tersisa bergotong royong untuk memulihkan kondisi koperasi. Pelajaran penting yang dapat dipetik dari peristiwa itu adalah Kopwan SBW telah menanamkan kepada anggotanya untuk belajar mandiri, berpikir optimis, bekerjasama dengan kompak dalam kondisi apapun, dan yakin pada kekuatan internal sehingga semakin matang serta lebih siap untuk menghadapi tantangan masa depan yang kian kompetitif.

\section{Keanggotaan Kopwan SBW Malang}

Kopwan SBW Malang mempunyai mekanisme penerimaan anggota yang cukup mudah dan praktis. Pertama, seorang calon anggota (wanita) diberi kesempatan untuk mengaajukan permintaan secara tertulis kepada pengurus sesuai dengan rekomendasi dari kelompok. Kedua, persyaratan untuk menjadi anggota tidak rumit dan mudah dipenuhi oleh masyarakat menengah ke bawah. Para anggota bergabung dengan kopwan SBW Malang berdasarkan kesadaran sendiri, kemauan sendiri, dan tidak ada faktor keterpaksaan. Pola rekrutmen bersifat terbuka, memberi kesempatan bagi calon anggota untuk mengambil keputusan atau berunding dengan keluarga masing-masing.

Kegiatan anggota dihimpun dan dikoordinir secara berkelompok yang anggotanya berjumlah 15 - 30 orang dengan mempertimbangkan kedekatan tempat tinggal masing-masing. Kopwan SBW selalu memberikan ruang yang seluas-luasnya untuk terbentuknya kelompok baru, yang dibentuk atas dasar kesepakatan bersama anggota kelompok yang kemudian disahkan oleh pengurus. Setiap kelompok harus memilih seorang penanggung jawab yang akan mengkoordinir agenda kelompok dan pertemuan rutin yang dilaksanakan sebulan sekali. Untuk menjadi penghubung antara pengurus dengan kelompok maka dibentuklah pembina penyuluh lapangan (PPL) yang bertanggung jawab atas 10-15 kelompok. PPL ini bertanggung jawab untuk pembinaan dan koordinasi denga sejumlah kelompok dan terus melakukan koordinasi dengan pengurus.

Tabel 1

Jumlah anggota kopwan SBW Malang

\begin{tabular}{|c|c|c|}
\hline Data & Tahun 2007 & Tahun 2008 \\
\hline Jumlah anggota & 4.084 & 5.296 \\
\hline Jumlah kelompok & 357 & 302 \\
\hline
\end{tabular}

Sumber : Kopwan SBW Malang, 2008 
Anggota terdiri dari anggota individu dan bina usaha kelompok pengusaha pedagang kecil (KPPK). Peran kopwan SBW dalam menghimpun KPPK sangat strategis karena akan dapat membantu usaha kecil untuk bangkit dan mengisi ruang niaga masyarakat dan tidak banyak koperasi yang melakukan hal ini. KPPK banyak mengalami kesulitan dalam permodalan, mereka kesulitan untuk mendapatkan akses pinjaman modal ke bank karena bank memiliki standar kriteria peminjaman yang ketat, rumit, dan tidak mudah dipenuhi oleh rakyat kecil. Selain memberikan pinjaman modal, kopwan SBW juga terus melakukan pembinaan dan mengawal proses berlangsungnya usaha hingga benar-benar berhasil.

Anggota sangat beragam yang terdiri dari pedagang di pasar, pemilik toko, warung, pekerja pabrik, pengusaha catering, bengkel, dll yang tersebar di seluruh kota dan Kabupaten Malang serta Batu. Koperasi dan UMKM dapat merekrut tenaga kerja informal sehingga dapat mengurangi pengangguran (Berita Jatim. 2009)

Kopwan SBW Malang merupakan lembaga usaha yang tidak hanya berorientasi pada laba tetapi juga pendidikan bagi anggotanya. Ini tercermin dengan adanya pendidikan dan pelatihan bagi karyawan, PPL, pengurus, dan anggota. Kopwan SBW juga memikirkan bagaimana memberikan manfaat yang sebesar-besarnya bagi anggota dan masyarakat yaitu mencapai kemandirian personal dan organisasi. Semua anggota diharapkan mampu memahami sistem kerja koperasi, mekanisme yang berlaku di koperasi secara langsung (dalam aktifitas usaha koperasi), dan melalui pelatihan, diklat dan diskusi yang dilakukan secara rutin. Kopwan SBW juga merupakan lembaga usaha yang transparan, inklusif, dan terbuka untuk melaksanakan kerjasama dengan pihakpihak lain.

Salah satu tujuan kopwan SBW adalah membangun kesejahteraan anggota. Orang bergabung dengan kopwan SBW tentu sadar bahw a mereka memiliki hak dan peluang untuk sejahtera secara bersam-sama.

\section{Unit Usaha Kopwan SBW Malang}

Kopwan SBW Malang mempunyai dua unit usaha yaitu : Unit usaha simpan pinjam dan unit usaha swalayan/waserda. 
Tabel 2

Volume / omzet usaha

\begin{tabular}{|c|c|c|}
\hline Unit usaha & Tahun 2007 & Tahun 2008 \\
\hline Unit simpan pinjam & 14.509 .760 .000 & 18.385 .300 .000 \\
\hline Unit waserda & 7.633 .529 .125 & 7.316 .441 .240 \\
\hline Jumlah & 22.143 .289 .125 & 25.701 .741 .240 \\
\hline
\end{tabular}

Sumber : Kopwan SBW Malang, 2008

Berdasarkan laporan keuangan 31 Desember 2008, total aset koperasi sebesar Rp. 16.986.285.654 meningkat 20,83\% dari tahun 2007 yang sebesar Rp. 14.070.297.897. Perkembangan usaha kopwan SBW mengalami kemajuan setiap tahunnya, hal ini dibuktikan dengan adanya peningkatan omzet usaha.

\section{Sistem Tanggung Renteng pada Kopwan SBW Malang}

Penerapan konsep tanggung renteng pada kopwan SBW Malang meliputi:

1. Tanggung renteng dalam proses pengambilan keputusan

2. Tanggung renteng dalam masalah finansial (simpanan dan pengelolaan keuntungan)

3. Tanggung renteng dalam menghadapi resiko usaha

4. Tanggung renteng dalam memikul beban organisasi terutama menyangkut masa depan koperasi

Sistem tanggung renteng akan lebih mudah dipahami dalam contoh yang sederhana. Misalnya sebuah koperasi terdiri dari beberapa kelompok dan satu kelompok terdiri dari 20 orang kemudian salah satu anggota membutuhkan dana dan dia ingin meminjam uang dari koperasi, maka kedua puluh orang anggota kelompok tersebut bermufakat untuk menyetujui pinjaman atau tidak, merumuskan aturan pengembalian, bentuk cicilan, dsb dengan tingkat resiko dan keuntungan yang ditanggung bersama. Cara ini sangat menarik mengingat adanya otonomi wewenang penentuan anggota yang berhak mendapatkan pinjamandana. Karena para anggota kelompoklah yang lebih mengetahui kebutuhan dan kesanggupan anggota dalam mempertanggungjawabkan dana yang dipinjam. Jika karena suatu hal anggota yang meminjam tadi tidak dapat membayar cicilan maka cicilan itu akan ditanggung bersama oleh seluruh anggota kelompok tersebut sehingga tidak ada penunggakan cicilan pada 
koperasi. Proses inilah yang terbukti dapat mengamankan asset koperasi dengan tunggakan $0 \%$.

Namun, atas kesepakatan dari anggota kelompok, biasanya setiap kelompok mempunyai dana cadangan yang disebut dana tanggung renteng (dana TR). Dana TR dikeluarkan apabila ada anggota yang tidak dapat membayar angsuran sehingga anggota yang lain merasa lebih ringan dibandingkan dengan cara membayar secara spontan pada saat ada anggota yang diTR.

Di dalam kelompok tanggung renteng harus ada seorang penanggung jawab yang bertugas mengkoordinir dan sebagai fasilitator terselenggaranya pertemuan kelompok serta bertanggung jawab atas lengkap tidaknya jumlah angsuran yang disetorkan ke koperasi. Pertemuan kelompok secara rutin menjadi hal yang wajib karena bagaimana bisa muncul jiwa kebersamaan bila diantara anggota tidak terjadi interaksi dan kemauan saling menanggung tidak akan timbul tanpa adanya jiwa kebersamaan. Hal inilah yang membedakan antara koperasi simpan pinjam dengan tanggung renteng dan koperasi simpan pinjam lainnya.

Para anggota juga di dorong untuk menabung melalui berbagai jenis simpanan yang tentu saja nominalnya sangat terjangkau oleh masyarakat kelas bawah. Simpanan ini terdiri dari simpanan pokok, simpanan wajib, simpanan wajib partisipasi, dan simpanan manasuka (biasa dan berjangka) yang selain terjangkau juga aman dan menguntungkan anggota.

Sistem tanggung renteng ini telah berhasil dikembangkan oleh kopwan SBW Malang. Untuk itu, kementrian koperasi dan UKM telah mereplikasikan sistem tanggung renteng tersebut melalui rintisan di daerah-daerah lain dengan memberikan dukungan dana bergulir sebesar Rp. 225 juta kepada 30 kelompok yang tersebar di 30 propinsi (Setia Bhakti Wanita, 2009). Sistem tanggung renteng yang berlaku di Kopwan SBW memberikan pendidikan langsung kepada anggota untuk mengenal seluk beluk berorganisasi, mengetahui konstelasi dunia usaha, dan yang tidak kalah penting adalah anggota dapat bekerja atas dasar gotong royong yang merupakan tradisi luhur bangsa Indonesia. 


\section{Tata Nilai dalam Sistem Tanggung Renteng}

Orang-orang yang belum memahami sistem tanggung renteng sering bertanya "kok mau-maunya menanggung angsuran anggota lain?", oleh karena itu harus ada proses seleksi dalam penerimaan anggota baru. Ketika calon anggota mengajukan permohonan untuk menjadi anggota maka dia diberi pemahaman terlebih dahulu tentang sistem tanggung renteng dan dia dapat diterima jika mempunyai komitmen dan sepakat menerima sistem tenggung renteng dengan segala konsekuensinya.

Sistem ini menuntut adanya kedisiplinan setiap anggota, mereka harus tepat waktu dalam menghadiri pertemuan kelompok karena jika ada anggota yang tertinggal dalam pertemuan kelompok sehingga kewajiban angsuran juga tertinggal maka akan menjadi tanggungan seluruh anggota dalam kelompok tersebut. Dengan pola demikian akan muncul rasa malu diantara mereka jika sampai lalai dalam pemenuhan kewajibannya. Kontrol dan saling mengingatkan akan memunculkan rasa tanggung jawab dari setiap anggota terhadap eksistensi dirinya sendiri maupun kelompoknya. Selain itu jika ada anggota yang jarang menghadiri pertemuan kelompok maka dia akan kesulitan mendapatkan persetujuan anggota lain ketika mengajukan pinjaman karena dia tidak memberikan persetujuan pada saat anggota yang lain mengajukan pinjaman. Hal ini akan memunculkan rasa empati terhadap sesama.

Pada dasarnya jika sistem tanggung renteng diterapkan dengan benar akan menumbuhkan pola pikir yang rasional dan bertanggung jawab karena ketika mengajukan pinjaman, anggota menyadari bahwa dana yang dipinjam itu adalah milik seluruh anggota koperasi. Jadi kalau kewajiban diabaikan sama artinya dengan merugikan seluruh anggota. Kebersamaan anggota benar-benar dibangun sehingga masing-masing dapat saling mendukung satu sama lain. Sistem tanggung renteng telah manjadi roh dan merupakan salah satu faktor utama majunya kopwan SBW Malang.

\section{Peranan Wanita dalam Kopwan SBW Malang}

Peran wanita dalam pemberdayaan dan pembangunan KUKM memiliki kecenderungan yang meningkat. Salah satu indikasi yang nampak di lapangan menunjukkan bahwa koperasi yang dikelola oleh kaum wanita memiliki kinerja 
yang relatif baik, antara lain seperti yang ditunjukkan oleh kopwan SBW Malang. Strategi untuk memberdayakan kaum wanita khususnya pelaku usaha skala mikro dan kecil antara lain dilakukan melalui peningkatan produktifitas usahanya. Untuk itu kementrian koperasi dan UKM telah memberikan penguatan pada kelompok-kelompok kegiatan produktif masyarakat, yang pada umumnya adalah wanita pengusaha skala mikro dan kecil yang berupa dana bergulir yang dikelola dengan penerapan sistem tanggung renteng (Puskowanjati, 2009). Dengan sistem tanggung renteng diharapkan dapat tercipta suasana kebersamaan kelompok dalam tanggung jawab secara kolektif, untuk mendapatkan manfaat yang sebesar-besarnya bagi berkembangnya usaha anggota kelompok, sehingga lebih lanjut mampu menumbuhkan kegiatan ekonomi produktif masyarakat.

Anggota kopwan SBW Malang adalah kaum wanita. Mereka mendapatkan keuntungan yang bersifat materiil dan moril seperti kemudahan dalam peminjaman modal usaha atau biaya pendidikan anak, mendapatkan akses usaha yang mudah dan cepat, berada dalam jaringan usaha (koperasi) yang terpercaya, memiliki banyak relasi, bisa bersosialisasi dengan orang banyak, bisa mendapatkan hak pemberdayaan SDM, dsb. Lebih dari itu, mereka menjadi bagian dari organisasi wanita yang peduli pada kaum perempuan dalam mendapatkan martabatnya dan membuktikan bahwa perempuan adalah sosok yang bisa mandiri, berguna, memiliki kekuatan strategis bagi hidupnya dan sektor ekonomi di negeri ini.

Kopwan SBW sebagai wahana usaha bersama membuka pintu bagi para wanita untuk secara bersama-sama berkumpul, sama-sama belajar, berusaha dan pada saatnya akan mendapatkan keuntungan. Banyak anggota yang semula hanya memiliki kemauan dan tekad, pada akhirnya bisa mandiri dan sejahtera bahkan bisa mensejahterakan orang lain, menciptakan lapangan kerja, dll.

Kopwan SBW tidak hanya berorientasi usaha tapi juga sebagai wahana pengkaderan wanita di Malang Raya yaitu sebagai pusat belajar kaum wanita dan pusat berinteraksi sosial. Kader-kader banyak ikut serta dalam forum-forum perempuan di kancah nasional dan internasional misalnya pada acara konferensi perempuan koperasi se-Asia Pasifik di Tagatay Filipina dan memenuhi undangan Uni Eropa Micro Finance untuk presentasi di Brussel. Dengan 
demikian wanita mempunyai peranan yang penting dalam pembangunan. Wanita perlu menggali potensinya, mengembangkan dan membuktikan kemampuannya sehingga apa yang populer disebut inner beauty akan terpancar. Bobot pengakuan akan sumber daya wanita akan semakin tinggi jika perannya konstruktif seperti yang kini dikembangkan oleh kopwan SBW.

Untuk meningkatkan partisipasinya sebagai bagian dari wahana perjuangan kaum wanita maka kopwan SBW mempunyai dua format utama yaitu :

1. Penguatan kualitas secara internal, yaitu dengan pemberdayaan internal anggota berupa pembinaan yang bersifat praktis dan pembinaan yang bersifat idealis seperti peran para kader SBW di ranah gender. Salah satu wujud riil dari pemberdayaan internal ini adalah program kepedulian Yayasan Bina Usaha Lingkungan (YBUL) yang membantu proses pemulihan usaha anggota yang bangkrut dan tentu saja tetap dalam semangat tanggung renteng. Konsep ini jarang dimiliki oleh lembaga ekonomi lainnya namun sangat dibutuhkan oleh masyarakat.

2. Memperluas akses dan interaksinya terutama yang berhubungan dengan entitas gender serta aktif dalam kerjasama antara lembaga-lembaga gender baik lokal, nasional, maupun internasional.

\section{KESIMPULAN DAN SARAN}

\section{Kesimpulan}

1. Koperasi Wanita Setia Budi Wanita Malang telah menerapkan sistem tanggung renteng sejak awal berdirinya. Penerapan sistem tanggung renteng meliputi tanggung renteng dalam proses pengambilan keputusan, tanggung renteng dalam masalah finansial (simpanan dan pengelolaan keuntungan), tanggung renteng dalam menghadapi resiko usaha, dan tanggung renteng dalam memikul beban organisasi terutama menyangkut masa depan koperasi. Keberhasilan penerapan sistem tersebut ditunjukkan dengan peningkatan jumlah anggota, aset, omzet usaha, dan keuntungan koperasi. 
2. Wanita mempunyai peranan penting dalam kemajuan kopwan SBW dan kesejahteraan keluarga dan masyarakat sehingga wanita ikut andil dalam pembangunan ekonomi nasional.

\section{Saran}

1. Bagi kopwan SBW Malang, untuk membuka kerjasama dengan perguruan tinggi dan lembaga-lembaga lain yang berkompeten dalam bidang penelitian untuk mensosialisasikan sistem tanggung renteng agar sistem ini lebih dikenal oleh masyarakat luas.

2. Bagi peneliti selanjutnya, perlu meneliti tentang pengaruh sistem tenggung renteng terhadap non performing loan karena ada indikasi sistem tanggung renteng dapat meminimalisasi kredit macet.

\section{DAFTAR PUSTAKA}

Berita Jatim. 2009. Koperasi dan UMKM dapat Mengurangi Pengangguran. TVRI Jawa Timur.

Hasan, M. Iqbal. 2003. Pokok-pokok Materi Metodologi Penelitian dan Aplikasinya. Jakarta: Ghalia Indonesia.

Idrus, Salim Al. 2007. Strategi Pengembangan Koperasi Indonesia Menuju Koperasi Mandiri. Jurnal Iqtishoduna, Fakultas Ekonomi UIN Malang.

Indiyon, Daru. 2006. Rahasia Sukses Tanggung Renteng Membangun Bisnis, Puskowanjati.

Laporan Pertanggungjawaban Pengurus dan Hasil Pengawasan Pengawas Tahun Buku 2007. 2007. Kopwan SU Setia Budi Wanita Malang.

Laporan Pertanggungjawaban Pengurus dan Hasil Pengawasan Pengawas Tahun Buku 2008. 2008. Kopwan SU Setia Budi Wanita Malang.

Masyhuri dan Zainudin. 2006. Metode Penelitian. UIN Press Malang.

Puskowanjati. Tanggung Renteng. //H:/Tanggung renteng/puskowanjati.htm. didownload tanggal 10-2-2009.

Setia Bhakti Wanita. Sejarah Tanggung Renteng. //H:/Tanggung renteng/sejarah-tanggung-renteng.html. didownload tanggal 10-2-2009.

Setia Budi Wanita. Peningkatan Peran Perempuan dalam Pemberdayaan KUKM. G:Tanggung renteng/ITR-peran perempuan.htm. didownload tanggal 102-2009.

Setia Budi Wanita. Sistem Tanggung Renteng. //H:/Tanggung renteng/renteng.php.htm. didownload tanggal 10-2-2009. 